\title{
Gambaran Kadar Protein Urin pada Ibu Hamil Trimester III di Rumah Sakit Robert Wolter Mongisidi Manado
}

\author{
${ }^{1}$ Angelo P. Pangulimang \\ ${ }^{2}$ Stefana H. M. Kaligis \\ ${ }^{2}$ Michaela E. Paruntu
}
${ }^{1}$ Program Studi Pendidikan Dokter Fakultas Kedokteran Universitas Sam Ratulangi Manado
${ }^{2}$ Bagian Biokimia Fakultas Kedokteran Universitas Sam Ratulangi Manado
Email: angelopahlawanto@gmail.com

\begin{abstract}
One of the causes of death among pregnant women is preeclampsia/eclampsia. The presence of protein in urine (proteinuria) in pregnant women is one of the signs of preeclampsia/eclampsia. This study was aimed to obtain the description of urine protein level in third trimester pregnant women at Robert Wolter Mongisidi Hospital Manado. This was a descriptive study with a cross sectional design. This study was conducted from August to December 2018 at Obstetry Clinic Robert Wolter Mongisidi Hospital. Samples were obtained by using total sampling technique. There were 39 subjects in this study based on inclusion and exclusion criteria. The results showed that 30 subjects $(76.93 \%)$ had no proteinuria (negative result) and 9 subjects (23.07\%) had proteinuria (positive result). Conclusion: Most of the third trimester pregnant women at Robert Wolter Mongisidi Hospital Manado had no proteinuria (negative result).
\end{abstract}

Keywords: proteinuria, pregnant woment, third trimester pregnancy

\begin{abstract}
Abstrak: Salah satu penyebab kematian pada ibu hamil ialah preeklamsia/eklamsia. Kehadiran protein dalam urin (proteinuria) pada ibu hamil merupakan salah satu tanda dari preeklamsia/eklamsia. Penelitian ini bertujuan untuk mengetahui gambaran kadar protein dalam urin ibu hamil trimester III di Rumah Sakit Robert Wolter Mongisidi. Jenis penelitian ialah dekriptif dengan desain potong lintang. Penelitian dilakukan pada bulan AgustusDesember 2016 di Poli Kebidanan Rumah Sakit Robert Wolter Mongisidi Manado. Pengambilan sampel dilakukan dengan metode total sampling. Terdapat subyek penelitian sebanyak 39 orang. Hasil penelitian menunjukkan 30 subjek $(76,93 \%)$ dengan protein dalam urin negatif dan 9 subjek $(23,07 \%)$ dengan protein positif. Simpulan: Pada sebagian besar ibu hamil trimester III di Rumah Sakit Robert Wolter Mongisidi Manado tidak didapatkan protein dalam urin.
\end{abstract}

Kata kunci: proteinuria, ibu hamil, hamil trimester III

Angka kematian ibu (AKI) merupakan salah satu indikator yang dapat menggambarkan kesejahteraan masyarakat disuatu negara. Menurut data World Health Organization (WHO), angka kematian ibu di dunia pada tahun 2015 sebanyak 216 per 100.000 kelahiran hidup atau diperkirakan jumlah kematian ibu yaitu 303.000 kematian dengan jumlah tertinggi berada di negara berkembang yaitu sebesar 302.000 kematian. ${ }^{1}$ Berdasarkan data profil kesehatan Provinsi Sulawesi Utara pada tahun 2016, penyebab kematian ibu bersalin disebabkan oleh pendarahan (22 kasus), hipertensi dalam kehamilan (preeklamsia dan eklam-sia) (13 kasus), infeksi (5 kasus), dan penyebab lain (31 kasus). ${ }^{2}$

Proteinuria merupakan salah satu 
kriteria diagnosis preeklamsia dan eklamsia. Proteinuria adalah terdapatnya protein dalam urin yang jumlahnya melebihi 150 $\mathrm{mg} / 24$ jam. Proteinuria dapat ditemukan dalam keadaan fisiologis yang jumlahnya kurang dari $200 \mathrm{mg} /$ hari dan bersifat sementara, misalnya pada keadaan demam tinggi, gagal jantung, aktifitas fisik berat, pasien dalam keadaan tranfusi darah, dan pasien yang kedinginan. ${ }^{3}$ Proteinuria patologik yaitu bila kadar protein urin melebihi $200 \mathrm{mg} /$ hari pada beberapa kali pemeriksaan dalam waktu yang berbeda. Proteinuria yang berat disebut massif yang terjadi terutama pada keadaan nefrotik dimana kadar protein dalam urin lebih dari 200 $\mathrm{mg} / 24$ jam pada orang dewasa. Biasanya berhubungan secara bermakna dengan lesi atau kebocoran glomerulus. Proteinuria di klasifikasikan menjadi proteinuria glomerular, tubular, overflow dan terisolasi (ortostatik dan fungsional). ${ }^{3}$

Penyebab proteinuria ialah: 1) terjadi perubahan permeabilitas glomerulus dan meningkatnya filtrasi protein plasma yang normal terlebih khusus albumin; 2) tubuli gagal mengabsorbsi beberapa jenis protein yang normal dapat difiltrasi; 3) tidak normalnya filtrasi glomerulus dan low molecular weight protein (LMWP) dengan jumlah melebihi kapasitas reabsorbsi tubuli; dan 4) meningkatnya sekresi makulo protein uroepitel dan sekresi $\operatorname{IgA}{ }^{3}$ Pada kehamilan normal, protein yang diekskresi dalam urin meningkat pada $5 \mathrm{mg} / \mathrm{dL}$ pada trimester pertama dan kedua serta 15 $\mathrm{mg} / \mathrm{dL}$ pada trimester ketiga. ${ }^{4}$

\section{METODE PENELITIAN}

Jenis penelitian yang dilakukan ialah deskriptif dengan desain potong lintang. Penelitian dilaksanakan di Poli Kebidanan Rumah Sakit Robert Wolter Mongisidi pada bulan Juli sampai Desember 2018. Subyek penelitian yaitu ibu hamil trimester III di Poli Kebidanan yang bersedia berpartisipasi dalam penelitian, diperoleh dengan total sampling.
Pemeriksaan protein dalam urin dilakukan menggunakan metode dipstik,

\section{HASIL PENELITIAN}

Hasil penelitian mendapatkan 39 orang ibu hamil trimester III yang memenuhi kriteria inklusi dan eklusi yang menjadi subjek penelitian. Berdasarkan hasil pemeriksaan diperoleh 30 orang $(76,92 \%)$ dengan protein urin negatif dan 9 orang $(23,08 \%)$ dengan protein urin positif (Tabel 1).

Tabel 1. Hasil pemeriksaan kadar protein urin dengan metode dipstik

\begin{tabular}{lcc}
\hline $\begin{array}{c}\text { Hasil } \\
\text { pemeriksaan }\end{array}$ & $\begin{array}{c}\text { Jumlah } \\
(\mathbf{n})\end{array}$ & $\begin{array}{c}\text { Persentase } \\
(\boldsymbol{\%})\end{array}$ \\
\hline Negatif & 30 & 76,92 \\
Positif + & 8 & 20,51 \\
Positif ++ & 1 & 2,57 \\
Positif +++ & - & - \\
Positif ++++ & - & - \\
Total & 39 & 100 \\
\hline
\end{tabular}

Berdasarkan usia subjek terdapat 3 orang berusia $\leq 20$ tahun, 29 orang berusia 21-34 tahun, 7 orang berusia $\geq 35$ tahun. Dari 9 subjek dengan urin positif mengandung protein, 4 orang berada pada rentang usia $\leq 20$ tahun dan $\geq 35$ tahun dan 5 orang pada usia 21- 34 tahun (Tabel 2).

Tabel 2. Persentasi ibu hamil dengan protein positif pada urin berdasarkan usia

\begin{tabular}{lcc}
\hline \multicolumn{1}{c}{ Usia } & $\begin{array}{c}\text { Proteinuria } \\
\text { positif }(\mathbf{n})\end{array}$ & $\begin{array}{c}\text { Persentase } \\
(\boldsymbol{\%})\end{array}$ \\
\hline$\leq 20$ dan & 4 & 44,44 \\
$\geq 35$ tahun & & \\
$21-34$ tahun & 5 & 55,56 \\
Total & 9 & 100 \\
\hline
\end{tabular}

Berdasarkan hasil pengukuran tekanan darah diperoleh sebanyak 37 subjek $(94,87 \%)$ memiliki tekanan darah normal dan 2 subjek $(5,13 \%)$ memiliki tekanan darah tinggi (hipertensi) (Tabel 3). Dari 2 subjek tersebut hanya 1 orang dengan proteinuria positif. 
Tabel 3. Persentase ibu hamil dengan protein positif pada urin berdasarkan tekanan darah

\begin{tabular}{ccccc}
\hline $\begin{array}{c}\text { Tekanan } \\
\text { darah }\end{array}$ & $\begin{array}{c}\text { Jumlah } \\
(\mathbf{n})\end{array}$ & $\begin{array}{c}\text { Persentase } \\
(\boldsymbol{\%})\end{array}$ & $\begin{array}{c}\text { Proteinuria } \\
\text { Positif }(\mathbf{n})\end{array}$ & $\begin{array}{c}\text { Persentase } \\
(\boldsymbol{\%})\end{array}$ \\
\hline Normal & 37 & 94,87 & 8 & 88,89 \\
Hipertensi & 2 & 5,13 & 1 & 11,11 \\
Total & 39 & 100 & 9 & 100 \\
\hline
\end{tabular}

\section{BAHASAN}

Berdasarkan hasil penelitian diperoleh sebagian besar $(76,92 \%)$ hasil pemeriksaan urin negatif untuk protein. Pada keadaan sehat dan kehamilan normal sebenarnya tidak terjadi peningkatan protein urin yang bermakna atau jumlahnya sampai di atas batas normal. Hanya sebagian protein dengan jumlah molekul kecil yang bisa ditemukan di urin. ${ }^{4}$

Hasil penelitian ini sejalan dengan penelitian yang dilakukan oleh Ni' $\mathrm{mah}^{5}$ pada ibu hamil trimester III di Rumah Bersalin Mattiro Baji Gowa dimana sebagian besar subjek $(87,8 \%)$ dengan hasil protein dalam urin negatif. Penelitian dari Arsani et $\mathrm{al}^{6}$ pada ibu hamil trimester II dan II di Puskesmas II Denpasar Barat juga mendapatkan sebagian besar ibu hamil trimester III $(70,83 \%)$ dengan hasil protein dalam urin negatif. Penelitian dari Iriani $^{7}$ pada ibu hamil di Puskesmas Kassi-Kassi Makasar juga mendapatkan sebagian besar subjek $(92,95 \%)$ dengan hasil protein dalam urin negatif.

Pada penelitian ini terdapat 9 subjek $(23,08 \%)$ yang urin positif mengandung protein. Hasil penelitian ini sejalan dengan penelitian dari Mustika dan Puspitaningrum $^{8}$ pada ibu hamil di Kota Semarang yang mendapatkan $14,29 \%$ hasil protein dalam urin positif. Hasil penelitian ini tidak selaras dengan penelitian yang dilakukan oleh Kurniadi et $\mathrm{al}^{9}$ pada ibu hamil di Kabupaten Sumba Barat Daya Nusa Tenggara Timur dimana sebagian besar subjek $(89,69 \%)$ dengan hasil protein dalam urin positif dan penelitian dari Taslim $^{10}$ pada ibu hamil di Puskemas Unaha Kabupaten Kanowe dimana ditemukan sebagian besar subjek $(78,13 \%)$ memiliki hasil protein dalam urin positif.
Penyebab hasil protein dalam urin positif dapat disebabkan oleh konsumsi protein berlebih, demam tinggi, aktifitas fisik berat, atau dapat juga disebabkan oleh penyakit seperti gangguan ginjal, preeklamsia, dan infeksi saluran kemih. Faktor yang berperan dalam munculnya proteinuria yaitu filtrasi glomerulus dan reabsorbsi protein tubulus. Pada preeklamsia proteinuria muncul karena kecepatan filtrasi glomerulus menurun. Seperti pada glomerulopati lainnya terdapat peningkatan permeabilitas terhadap sebagian besar protein dengan berat molekul yang besar. ${ }^{11,12}$

Kehamilan normal dihubungkan dengan peningkatan laju filtrasi glomerulus sebesar 40-65\% dan aliran plasma ke ginjal sebesar $50-85 \%$ selama awal pertama kehamilan. ${ }^{13}$ Protein yang diekskresi dalam urin meningkat pada kehamilan normal dari $5 \mathrm{mg} / \mathrm{dL}$ pada trimester pertama dan kedua serta $15 \mathrm{mg} / \mathrm{dL}$ pada trimester ketiga. ${ }^{4}$ Ketika munculnya hipertensi dalam kehamilan, aliran darah pada ginjal dan kecepatan filtrasi glomerulus menurun. Seperti pada glomerulopati lainnya terdapat peningkatan permeabilitas terhadap sebagian besar protein dengan berat molekul yang besar. Pada keadaan ini ditemukan ekskresi albumin yang abnormal disertai protein lainnya, seperti hemoglobin, globulin dan transferin dalam urin. Beberapa protein dengan berat molekul kecil biasanya difiltrasi namun kemudian direabsorbsi sehingga ditemukan di dalam urin. ${ }^{12}$

Dari 9 subjek yang dalam urinnya positif mengandung protein terdapat 4 subjek $(44,44 \%)$ yang berusia $\leq 20$ dan $\geq 35$ tahun. Hasil penelitian ini sejalan dengan penelitian yang dilakukan oleh Sengkey ${ }^{14}$ mengenai faktor risiko preeklamsia di BLU RSUP Prof. Dr. R.D. Kandou Manado 
dimana pada usia $\leq 20$ dan $\geq 35$ tahun terdapat $37,5 \%$ hasil protein dalam urin positif. Penelitian dari Hutabarat ${ }^{15}$ mengenai karakteristik pasien dengan preeklamsia di RSUP Prof. Dr. R.D. Kandou Manado melaporkan bahwa pada usia $\leq 20$ dan $\geq 35$ tahun terdapat $37,78 \%$ hasil protein dalam urin positif. Penelitian dari Kalam ${ }^{16}$ pada kehamilan dengan preeklamsia berat di RSUP Prof. Dr. R. D. Kandou Manado menyatakan bahwa pada usia $\leq 20$ dan $\geq 35$ tahun terdapat $30,77 \%$ hasil protein dalam urin positif. Usia ibu hamil risiko tinggi $(\leq 20$ dan $\geq 35)$ merupakan salah satu faktor penyebab preeklamsia dan protein urin menjadi salah satu kriteria diagnostik preeklamsia. $^{11}$

Dari 9 subjek yang urinnya positif mengandung protein terdapat 1 subjek $(2,57 \%)$ dengan tekanan darah tinggi. Hasil penelitian ini sejalan dengan penelitian yang dilakukan oleh Sengkey ${ }^{14}$ mengenai faktor risiko preeklamsia di BLU RSUP Prof. Dr. R.D. Kandou Manado yang mendapatkan $19,64 \%$ hasil protein dalam urin positif. Demikian pula penelitian oleh Kalam terhadap kehamilan dengan preeklamsia berat di RSUP Prof. Dr. R.D. Kandou Manado mendapatkan 10,8\% hasil protein dalam urin positif. Penelitian dari Lombo $^{17}$ mengenai karakteristik ibu hamil dengan preeklamsia di RSUP Prof. Dr. R.D. Kandou Manado mendapatkan 8,33\% dengan hasil protein dalam urin positif. Hipertensi dan proteinuria pada kehamilan merupakan dua dari tiga kriteria utama diagnostik pada preeklamsia. Pada penelitian ini ditemukan 1 subjek dengan protein dalam urin positif $(+1)$ yang disertai hipertensi. Diduga pasien ini berpeluang mengarah ke preeklamsia. ${ }^{11}$

Berdasarkan penelitian ini dari 9 subjek yang positif protein urin didapatkan 1 subjek $(2,56 \%)$ yang protein urin positif $(+2)$, tetapi tidak disertai hipertensi. Kemungkinan yang terjadi ialah gangguan ginjal yang belum diketahui subjek dan sudah ada sebelum kehamilan. ${ }^{3}$

\section{SIMPULAN}

Berdasarkan hasil penelitian yang dila- kukan di Poli Kebidanan Rumah Sakit Wolter Mongisidi dapat disimpulkan bahwa pada sebagian besar ibu hamil trimester III tidak didapatkan adanya protein dalam urin.

\section{DAFTAR PUSTAKA}

1. WHO, UNICEF, UNFPA, Group WB, Division UNP. Trends in maternal mortality: 1990 to 2015. Estim by WHO, UNICEF, UNFPA, World Bank Gr United Nations Popul Div. 2015;133.

2. RI Kesehatan. Infodatin Pusat Data dan Informasi Kementerian Kesehatan RI. Pusat Data dan Informasi Kementrian Kesehatan RI: Penyebab Kematian Ibu, 2014.

3. Bawazier LA. Buku Ajar Ilmu Penyakit Dalam (5th ed). Sudoyo A, Setiyohadi B, Alwi I, Simadibrata M, Siti S, editors. Jakarta: Interna Publishing, 2009; p. 956-61.

4. Sibai BM. Preeclampsia and Hypertensive Disorders (7th ed). Obstetrics: Normal and Problem Pregnancies. Elsevier Inc, 2016; p. 661-705.e3.

5. Ni'mah M. Gambaran kadar hemoglobin dan protein pada ibu hamil trimester III di Rumah Sakit Bersalin Gowa [Skripsi]. Makassar: Fakultas Kedokteran Universitas Islam Negeri Alauddin; 2017.

6. Asrani L, Merta I, Widyah C. kadar protein urin pada ibu hamil trimester II di Pusksmas II Denpasar Barat. Denpasar: Meditory, 2017.

7. Iriani. Gambaran angka kejadian proteinuria pada ibu hamil di Puskesmas KassiKassi Makasar [Skripsi]. Makasar: FIK-Universitas Islam Negeri Alauddin Makasar; 2014.

8. Mustika D, Puspitaningrum D. Pemeriksaan kadar hemoglobin dan urine pada ibu hamil di Laboratorium Kesehatan Terpadu UNIMUS [Skripsi]. Semarang: FIKKES Universitas Muhammadiyah Semarang; 2016.

9. Kurniadi A, Tanumihardja T, Pradiptaloka E. Status proteinuria dalam kehamilan di Kabupaten Sumba Barat Daya Nusa Tenggara Timur tahun 2016. J Kesehat Reproduksi. 2017;8(1):53-61.

10. Taslim A. Identifikasi status protein urine pada ibu hamil di Puskemas Unaha Kabupaten Kanowe [Skripsi]. Kendari: 
Poli Teknik Kesehatan Kemenkes Kendari; 2016.

11. Angsar D. Ilmu Kebidanan (4th ed). Prawirohardi S, editor. Jakarta: PT Bina Pustaka, 2016; p, 538.

12. Cunningham G, Gant N, Leveno $K$, Gilstrap L, Hauth J, Wenstrom K. Obstetri Williams (23rd ed). Jakarta: EGC, 2012; p.1090.

13. Karumanchi SA. Pregnancy and the Kidney. 2018;p. 319-45.

14. Sengkey J. Faktor risiko preeklamsia di BLU RSUP Prof. Kandou Manado tahun 2012 [Skripsi]. Manado; Fakultas Kedokteran Universitas Sam Ratulangi; 2014.

15. Hutabarat R. Karakteristik pasien dengan preeklamsia di RSUP Prof. Kandou Manado [Skripsi]. Manado Fakultas Kedokteran Universitas Sam Ratulangi Manado; 2015.

16. Kalam C. Luaran ibu dan prenatal pada kehamilan dengan preeklamsia berat di BLU RSUP Prof Kandou Manado Periode 1 Januari - 31 Desember 2016 [Skripsi]. Manado: Fakultas Kedokteran Universitas Sam Ratulangi Manado; 2014.

17. Lombo G. Karakteristik ibu hamil dengan preeklamsia di RSUP Prof Kandou Manado periode 1 Januari-31 Desember 2016 [Skripsi]. Manado; Fakultas Kedokteran Universitas Sam Ratulangi Manado; 2016. 